\title{
OBSERVATIONS OF RAPID COLONIZATION OF CONSTRUCTED PONDS BY WESTERN TOADS (BUFO BOREAS) IN OREGON, USA
}

\author{
Christopher A. Pearl ${ }^{1}$ and Jay Bowerman ${ }^{2}$
}

Key words: Bufo boreas, breeding, colonization, habitat, succession, western toad.

Western toad (Bufo boreas complex) populations have declined from multiple portions of their historic range (Ross et al. 1995, Livo and Yeakley 1997, Corn 2003, Davis and Gregory 2003). Bufo boreas breeds in a wide variety of aquatic habitats including montane lakes (Nussbaum et al. 1983, Corn et al. 1997, Marnell 1997), ponds created by volcanic eruptions (MacMahon 1982, Karlstrom 1986), beaver impoundments (Corn et al. 1997, Marnell 1997), shifting side channels along lowland rivers (Carpenter 1953, Frissell and Cavallo 1997), and anthropogenic ponds and reservoirs (Nussbaum et al. 1983, Wente et al. 2005). Despite the diversity of habitats utilized by B. boreas, little is known about characteristics that make sites attractive for toad breeding. Improved understanding of breeding site selection and attributes of breeding habitat may be useful for conservation of $B$. boreas.

Other north temperate Bufo species such as B. americanus and B. calamita are reported to colonize new and disturbed ponds (Banks and Beebee 1987, Lehtinen and Galatowitsch 2001, Phillips et al. 2002), but the ability of B. boreas to find and breed in early successional sites is less well documented. Here we describe rapid colonization of newly excavated ponds by $B$. boreas in semiarid landscapes of central and eastern Oregon.

We documented breeding use by $B$. boreas in 6 newly constructed ponds (hereafter colonization) as part of ongoing amphibian monitoring in Deschutes and Baker Counties, Oregon (Table 1, Fig. 1). The ponds were between $1265 \mathrm{~m}$ and $1348 \mathrm{~m}$ in elevation and located in the High Lava Plains and Blue Mountain physiographic regions (Franklin and Dyrness 1973). Most (80\%-90\%) of the annual precipitation
$(30-40 \mathrm{~cm})$ falls between October and May (Franklin and Dyrness 1973). All ponds were surrounded by uplands of ponderosa pine (Pinus ponderosa), lodgepole pine (P. contorta), and sage (Artemisia sp.) or bitterbrush (Purshia spp.). Two ponds (Dilman A and Sunriver Golf Hazard) were bordered by a wet meadow and an irrigated golf course, respectively, before grading into ponderosa-lodgepole forest at distances $>50 \mathrm{~m}$. Two ponds (Pine A and B) were in a dry gulch in moderately sloping foothill topography (slope along temporary stream 7\%; slope of bordering hillsides 9\%-22\%). Terrain surrounding the remaining 4 ponds was flat or gently sloping $(<3 \%)$. All ponds were in forest openings that allowed high insolation and held water throughout the summer in each year of observation.

We confirmed breeding of B. boreas by directly observing eggs, larvae, or metamorphic individuals (Table 1). We determined month of breeding either through direct observation of eggs or hatchlings or by comparison of developmental stages with other sites in the region. Pond dimensions were estimated visually or by pacing. We estimated straightline distance from each new pond to the nearest known $B$. boreas breeding site from USGS topographic quadrangle maps. We have surveyed all known ponds and lakes within $10 \mathrm{~km}$ of the colonized ponds, so it is unlikely that $B$. boreas breeding regularly occurred closer than our estimates.

Bufo boreas bred in all 6 ponds in the 1st spring following construction (range 2-9 months after construction; Table 1). Five of 6 colonized ponds were small $\left(\leq 500 \mathrm{~m}^{2}\right.$ of surface area), and all ponds had little or no aquatic macrophytic vegetation. Based on numbers of egg

1USGS Forest and Rangeland Ecosystem Science Center, 3200 SW Jefferson Way, Corvallis, OR 97331. E-mail: christopher_pearl@usgs.gov

${ }^{2}$ Sunriver Nature Center, Box 3533, Sunriver, OR 97707. 


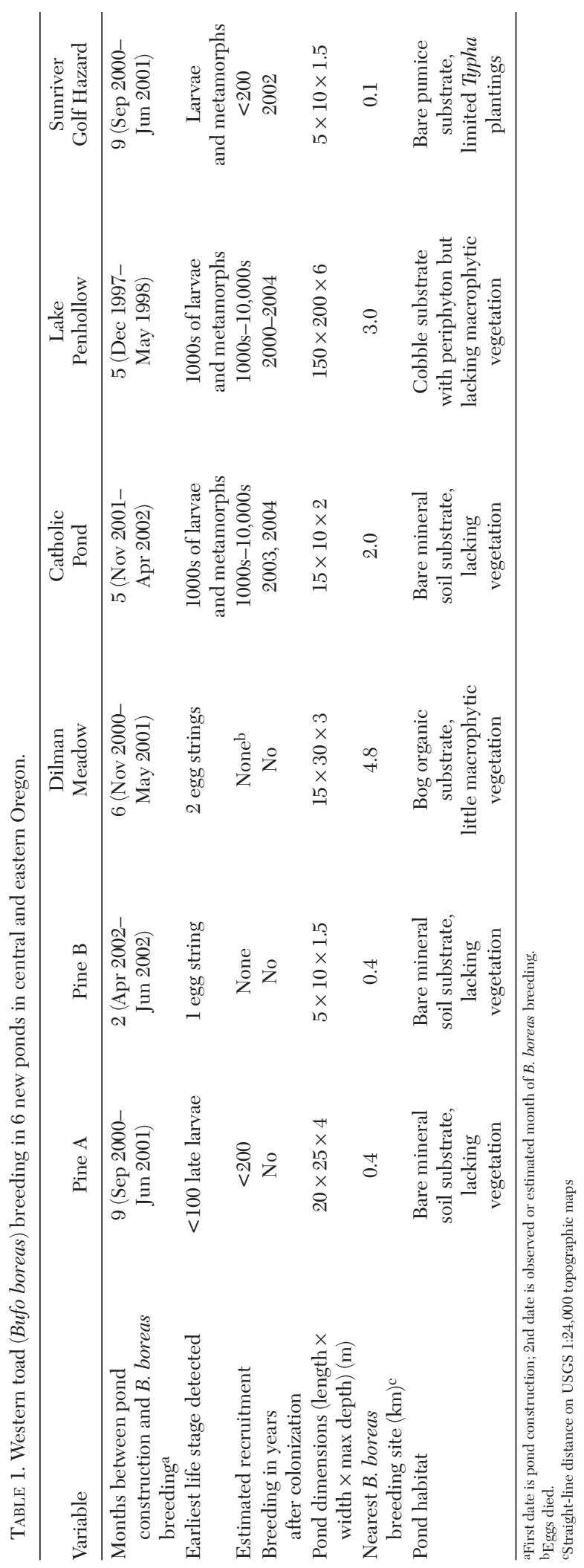




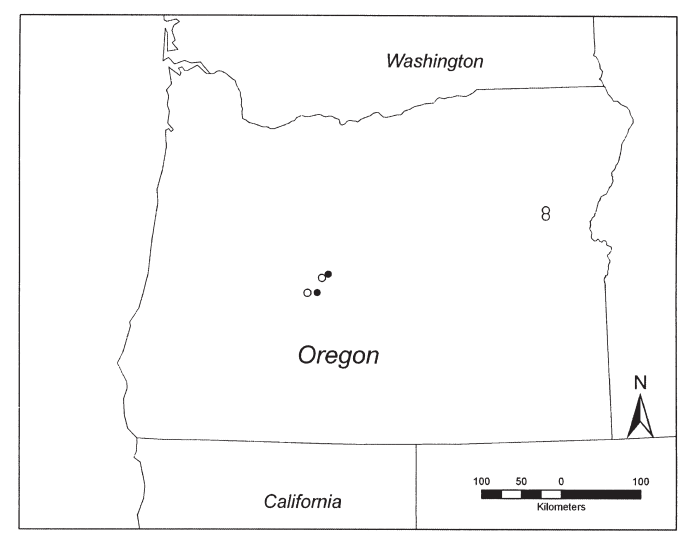

Fig. 1. Locations of Bufo boreas colonization sites in Oregon. Filled circles are sites with moderate to high breeding and recruitment (Catholic Pond, Lake Penhollow); open circles are sites with limited breeding.

strings, larvae, and juveniles, we estimated that breeding effort was small ( $\leq 3$ clutches) in 4 of 6 ponds. We observed little or no recruitment of juveniles ( $<100$ observed) at these 4 sites. Large numbers of juvenile $B$. boreas were recruited at the other 2 sites: 10,000s at Lake Penhollow and 1000s-10,000s at Catholic Pond. Juvenile recruitment at Lake Penhollow was similar in the 1st and 2nd years after colonization, and we observed $\geq 20$ pairs of $B$. boreas breeding at that site in the 2 nd year. $B u f o$ boreas continues to breed in both sites that supported substantial juvenile recruitment in their 1st year (Catholic Pond, Lake Penhollow). Both sites are lined with impermeable substrate and lack macrophytic vegetation. With the exception of 2nd-year breeding at Sunriver Golf Hazard, we have not observed subsequent B. boreas breeding in any of the 4 sites that had limited or no recruitment in the 1st year.

In the Pine Creek drainage, B. boreas bred in each of 2 new ponds in their respective 1st year after excavation (2001, 2002). The local historic breeding pond, which supported breeding from 1997 to 2000, was unused in 2001 and 2002. Breeding resumed at the historic site in 2003 and 2004.

Our observations indicate that $B$. boreas can rapidly locate new breeding sites in semiarid landscapes where no surface water existed prior to pond excavation. Data from Washington and Montana also suggest $B$. boreas can colonize new and recently disturbed aquatic sites (Karl- strom 1986, B. Hossack personal communication). For example, within 1 year after the May 1980 eruption of Mount St. Helens buried the valley containing the North Fork of the Toutle River in avalanche debris $>75 \mathrm{~m}$ deep, $B$. boreas bred in at least 1 valley site (Jackson Lake; Karlstrom 1986). By 1985 B. boreas was the most common anuran breeding in 22 newly created ponds along the North Fork of the Toutle River (Karlstrom 1986). In the year immediately following 3 wildfires in Glacier National Park, Montana, B. boreas bred in 30 wetlands where the species had not been detected previously (Hossack personal communication). The nearest known breeding of $B$. boreas to many of the newly colonized sites was $\geq 1 \mathrm{~km}$ (Hossack personal communication). In both cases, terrestrial habitat around breeding ponds was predominately dry substrate with sparse or no vegetative cover (Karlstrom 1986, Hossack personal communication).

In our observations $B$. boreas bred in new sites located $0.1-4.8 \mathrm{~km}$ from the nearest potential source breeding sites. These distances are similar to those traveled by transmittered $B$. boreas in the northern Rocky Mountains. Adult B. boreas in Idaho (Bartelt et al. 2004) and Colorado (Muths 2003) use extensive home ranges (5.8-24.6 ha) and can travel $1-4 \mathrm{~km}$ to and from breeding sites within a year. Our observations and the interpond movements of 0.9-5.0 km reported by Thompson (2004) both indicate that movements to new breeding sites can be similar in magnitude to seasonal ranges. A link between capacity for long distance movements and ability to colonize new ponds has been hypothesized for both the American toad (B. americanus) in Minnesota (Lehtinen and Galatowitsch 2001) and the common toad (B. bufo) in Britain (Baker and Halliday 1999); the link may also apply to B. boreas in Oregon. Further work is needed to understand how factors such as topography, vegetation, surface moisture, and availability of existing ponds influence detection and use of new ponds.

We estimate that colonization events ranged from $<3$ pairs ( 2 sites) to $>20$ pairs of $B$. boreas (1 site; Table 1). Our small number of observations, combined with uncertainty about the locations of colonists' natal ponds, limit conclusions about factors affecting numbers of colonists. That the site with the largest numbers of colonists (Lake Penhollow) was among 
the farthest from potential historic breeding habitat suggests that factors other than distance can affect colonization intensity.

The Lake Penhollow case is of particular interest because it is $>3 \mathrm{~km}$ uphill and downwind from the nearest historic or potential breeding habitat; railroad tracks traverse direct routes between the two. More B. boreas bred in Lake Penhollow in the 1st and 2nd years after construction than in any nearby ponds during the same period or the previous 5 years (J. Bowerman unpublished data). The large cohort of $B$. boreas that colonized Lake Penhollow could reflect (1) the use of cues to detect this isolated site, (2) a reservoir of adult $B$. boreas residing in the surrounding forest, or (3) both. Breeding site selection by B. calamita in Britain is thought to be influenced by biotic (e.g., presence of competitors) and abiotic (e.g., warm shallows) attributes (Banks and Beebee 1987), but the cues used by $B$. boreas to assess these conditions are poorly known. Location of breeding sites by displaced B. calamita in Germany varied with sex: males used visual, olfactory, and magnetic cues to home toward breeding ponds, whereas females moved toward the nearest pond with a male chorus (Sinsch 1992). Many Pacific treefrogs (Pseudacris regilla) call in Lake Penhollow, although we do not know if treefrog presence preceded B. boreas colonization. Whether adult $B$. boreas can use the calls of other anurans to locate new ponds deserves investigation.

Ecological incentives may exist for $B$. boreas to colonize new ponds that differ from older or undisturbed ponds in attributes such as withinpond vegetation density, canopy shading, food quality, and predator and competitor communities (Baker and Halliday 1999, Lehtinen and Galatowitsch 2001). Vegetation succession in and around wetlands is an important factor in breeding site suitability for a variety of north temperate anurans, including B. americanus and B. calamita (Banks and Beebee 1987, Skelly et al. 1999, Werner and Glennemeier 1999, Phillips et al. 2002). Both of these congeners are reduced in older or undisturbed ponds (Banks and Beebee 1987, Petranka et al. 1994, Bardsley and Beebee 1998, Werner and Glennemeier 1999). Two of our colonized ponds (Catholic Pond, Lake Penhollow) have supported $B$. boreas breeding and juvenile recruitment every year since construction. Both ponds were constructed with an impermeable liner and, to date, have little or no macrophytic vegetation.

Our observations suggest that constructed ponds can be attractive to $B$. boreas in central and eastern Oregon, but that productivity and duration of breeding use can vary markedly between sites. Further research on the relationships between in-pond vegetation and breeding site suitability may clarify factors influencing colonization and juvenile recruitment. Whether colonization of new ponds benefits local and regional $B$. boreas populations also merits investigation.

These observations were made as part of work funded by the Oregon Community Foundation, U.S. Bureau of Reclamation, USDA Forest Service, and USGS Amphibian Research and Monitoring Initiative (ARMI). We thank B. Hossack, E. Muths, and 2 anonymous reviewers for comments that improved this manuscript.

\section{Literature Cited}

BaKer, J.M., AND T.R. Halliday. 1999. Amphibian colonization of new ponds in an agricultural landscape. Herpetological Journal 9:55-63.

BANKs, B., AND T.J.C. BEEBEE. 1987. Factors influencing breeding site choice by the pioneering amphibian Bufo calamita. Holarctic Ecology 10:14-21.

Bardsley, L., AND T.J.C. BEEBEE. 1998. Interspecific competition between Bufo larvae under conditions of community transition. Ecology 79:1751-1759.

Bartelt, P.E., C.R. Peterson, and R.W. Klaver. 2004. Sexual differences in the post-breeding movements and habits selected by western toads (Bufo boreas) in southeastern Idaho. Herpetologica 60:455-467.

Carpenter, C.C. 1953. An ecological survey of the herpetofauna of the Grand Teton-Jackson Hole area of Wyoming. Copeia 1953:170-175.

CoRn, P.S. 2003. Endangered toads in the Rockies. Pages 43-51 in L. Taylor, K. Martin, D. Hik, and A. Ryall, editors, Ecological and earth sciences in mountain areas. The Banff Centre, Banff, Alberta, Canada.

Corn, P.S., M.L. Jennings, And E. Muths. 1997. Survey and assessment of amphibian populations in Rocky Mountain National Park. Northwestern Naturalist 78:35-56.

Davis, T.M., AND P.T. GRegory. 2003. Decline and local extinction of the western toad, Bufo boreas, on southern Vancouver Island, British Columbia, Canada. Herpetological Review 34:350-352.

Franklin, J.F., And C.T. Dyrness. 1973. Natural vegetation of Oregon and Washington. Oregon State University Press, Corvallis. $452 \mathrm{pp}$.

Frissell, C.A., AND B.J. Cavallo. 1997. Aquatic habitats used by larval western toads, (Bufo boreas), on an intermontane river floodplain and some landscape 
conservation implications. Abstract. Supplement to Bulletin of Ecological Society of America 78:91.

KarLSTROM, E.L. 1986. Amphibian recovery in the North Fork Toutle River debris avalanche area of Mount St. Helens. Pages 334-344 in S.A.C. Keller, editor, Mount St. Helens: five years later. Eastern Washington University Press, Cheney.

Lehtinen, R.M., and S.M. Galatowitsch. 2001. Colonization of restored wetlands by amphibians in Minnesota. American Midland Naturalist 145:388-396.

Livo, L.J., AND D. YEAKLEY. 1997. Comparison of current with historic elevational range in the boreal toad, Bufo boreas. Herpetological Review 28:143-144.

MacMahon, J.A. 1982. Mount St. Helens revisited. Natural History 91:14-24.

MarnelL, L.F. 1997. Herpetofauna of Glacier National Park. Northwestern Naturalist 78:17-33.

Muths, E. 2003. Home range and movements of boreal toads in undisturbed habitat. Copeia 2003:160-165.

Nussbaum, R.A., E.D. Brodie, Jr., and R.M. Storm. 1983. Amphibians and reptiles of the Pacific Northwest. University Press of Idaho. Moscow. 353 pp.

Petranka, J.W., S.J. Boone, M.E. Hopey, S.D. Baird, and B. JENNINGS. 1994. Breeding habitat segregation of wood frogs and American toads: the role of interspecific tadpole predation and adult choice. Copeia 1994:691-697.
Phillips, R.A., D. Patterson, and P. Shimmings. 2002. Increased use of ponds by breeding natterjack toads, Bufo calamita, following management. Herpetological Journal 12:75-78.

Ross, D.A., T.C. Esque, R.A. Fridell, And P. Hovingh. 1995. Historical distribution, current status, and a range extension of Bufo boreas in Utah. Herpetological Review 26:187-189.

SINSCH, U. 1992. Sex-biased site fidelity and orientation behaviour in reproductive natterjack toads (Bufo calamita). Ethology, Ecology and Evolution 4:15-32.

Skelly, D.K., E.E. Werner, and S.A. Cortwright. 1999. Long-term distributional dynamics of a Michigan amphibian assemblage. Ecology 80:2326-2337.

Thompson, P.D. 2004. Observations of boreal toad (Bufo boreas) breeding populations in northwestern Utah. Herpetological Review 35:342-344.

Wente, W., M.J. Adams, and C.A. Pearl. 2005. Evidence of decline for Bufo boreas and Rana luteiventris in and around the northern Great Basin, western USA. Alytes 22(3-4):95-108.

Werner, E.E., AND K.S. Glennemeier. 1999. Influence of canopy cover on the breeding pond distributions of several amphibian species. Copeia 1999:1-12.

Received 15 February 2005 Accepted 30 August 2005 